\title{
MUSCLE ACTIVITY DURING ENDOTRACHEAL INTUBATION USING 4 LARYNGOSCOPES (MACINTOSH LARYNGOSCOPE, INTUBRITE, TRUVIEW EVO2 AND KING VISION) - A COMPARATIVE STUDY
}

\author{
AKTYWNOŚĆ MIĘŚNI W TRAKCIE INTUBACJI DOTCHAWICZEJ ZA POMOCA 4 LARYNGOSKOPÓW \\ (STANDARDOWEGO Z ŁOPATKA MACINTOSHA, INTUBRITE, TRUVIEW EVO2 I KING VISION) - \\ BADANIE PORÓWNAWCZE
}

Medical University of Lodz / Uniwersytet Medyczny w Łodzi, Łódź, Poland

Department of Emergency Medicine and Disaster Medicine / Zakład Medycyny Ratunkowej i Medycyny Katastrof

\begin{abstract}
Background: Successful endotracheal intubation requires mental activity and no less important physical activity from the anesthesiologist, so ergonomics of used devices is important. The aim of our study has been to compare 4 laryngoscopes regarding an operator's activity of selected muscles of the upper limb, an operator's satisfaction with used devices and an operator's fatigue during intubation attempts. Material and Methods: The study included 13 anesthesiologists of similar seniority. To measure muscle activity MyoPlus 2 with 2-channel surface ElectroMyoGraphy (sEMG) test device was used. Participant's satisfaction with studied devices was evaluated using Visual Analog Scale. An operator's fatigue during intubation efforts was evaluated by means of the modified Borg's scale. Results: The highest activity of all the studied muscles was observed for the Intubrite laryngoscope, followed by the Mackintosh, TruView Evo2 and the lowest one - for the King Vision video laryngoscope. A significant statistical difference was observed for the King Vision and the rest of laryngoscopes $(\mathrm{p}<0.05)$. No significant statistical differences were observed between the Macintosh, TruView Evo2 and Intubrite laryngoscopes ( $p>0.05$ ). The shortest time of intubation was achieved using the standard Macintosh blade laryngoscope. The highest satisfaction was noted for the King Vision video laryngoscope, and the lowest for - the TruView Evo2. The Intubrite was the most demanding in terms of workload, in the opinion of the participants', and the least demanding was the King Vision video laryngoscope. Conclusions: Muscle activity, namely the force used for intubation, is the smallest when the King Vision video laryngoscope is used with the highest satisfaction and lowest workload, and the highest muscle activity was proven for the Intubrite laryngoscope with the highest workload. Med Pr 2016;67(2):155-162
\end{abstract}

Key words: intubation, satisfaction, workload, muscle activity, anesthesiology, equipment

\section{STRESZCZENIE}

Wstęp: Udana intubacja dotchawicza wymaga od wykonującego ją anestezjologa umiejętności i sprawności fizycznej. Ponieważ stanowi też duże obciążenie fizyczne, ergonomia stosowanych urządzeń ma znaczenie. Celem badania było porównanie 4 laryngoskopów i ocena aktywności wybranych mięśni kończyny górnej oraz satysfakcji i zmęczenia u osób wykonujących intubację za ich pomocą. Materiał i metody: W badaniu wzięło udział 13 anestezjologów z podobnym stażem pracy. Aktywność mięśni mierzono przy użyciu aparatu do elektromiografii (ElectroMyoGraphy - EMG) MyoPlus 2. Satysfakcję intubujących określono w wizualnej skali analogowej (Visual Analog Scale - VAS), a zmęczenie oceniono zmodyfikowaną skalą Borga. Wyniki: Najwyższą aktywność mięśni odnotowano w przypadku intubacji wykonywanej za pomocą laryngoskopu Intubrite, następnie standardowego z łopatką Mackintosha, dalej - TruView Evo2, a najniższą w przypadku wideolaryngoskopu King Vision. Różnice istotne statystycznie w aktywności mięśni odnotowano dla King Vision i pozostałych laryngoskopów (p < 0,05), natomiast między pozostałymi urządzeniami nie zaobserwowano istotnych różnic ( $\mathrm{p}>0,05)$. Najkrócej trwała intubacja przeprowadzana z użyciem standardowego laryngoskopu. Najwyżej satysfakcję z wykonanej pracy oceniali badani korzystający z King Vision, a najniższej w przypadku TruView Evo2. Największe zmęczenie powodował u badanych używany do intubacji laryngoskop Intubrite, a najmniejsze - King Vision. Wnioski: Najniższa aktywność mięśni, czyli najmniejsza siła, są konieczne do wykonania intubacji za pomocą laryngoskopu King Vision. Korzystanie z tego urządzenia sprawia także największą satysfakcję i powoduje najmniejsze zmęczenie. Z kolei najwyższa aktywność mięśni i największy wysiłek są potrzebne do intubacji za pomocą Intubrite. Med. Pr. 2016;67(2):155-162

Słowa kluczowe: intubacja, satysfakcja, wysiłek fizyczny, aktywność mięśni, anestezjologia, sprzęt

Corresponding author / Autor do korespondencji: Tomasz Gaszyński, Barlicki University Hospital, Chair of Anaesthesiology and Intensive Therapy, Kopcińskiego 22, 90-153 Łódź, e-mail: tomasz.gaszynski@umed.lodz.pl Received: 2015, June 18, accepted: 2015, November 24 


\section{INTRODUCTION}

According to the standards of the American Society of Anesthesiologists, difficult intubation includes more than 2 attempts to perform classic laryngoscope intubation or intubation, which takes more than $10 \mathrm{~min}$. Successful endotracheal intubation requires mental activity and no less important physical activity from the anesthesiologist, which seems to be the most plausible when the laryngoscope is used[1]. In this case adaptation or physical labor to mental and physical capacity of the man we are dealing with seems to depend on nothing else but the ergonomics. Prolonged intubation efforts cause the fatigue of a provider and influence the success of the medical procedure. Therefore, you should know that there are ambient conditions for intubation devices that may be used for making intubation using little biological-activity of muscles, proving at the same time the highest efficiency.

The aim of our study has been to demonstrate which out of the tested equipment requires a minimum of an operator's activity of selected muscles of the upper limb and to compare these devices in correlation with the efficiency and the time necessary for the proper airway protection, an operator's satisfaction with used devices and an operator's physical fatigue during intubation attempts using studied devices.

The primary outcome has been the difference in ergonomics among 4 different laryngoscopes as measured by a degree of muscle activity. The secondary outcome has been the time needed to intubate using studied devices.

\section{MATERIAL AND METHODS}

The study included 13 anesthesiologists of similar seniority -8 men and 5 women (mean age: 28 years old, mean weight: $72 \mathrm{~kg}$, mean height: $171 \mathrm{~cm}$ ) with righthanded laterality. Before the trials, participants were reminded of the correct posture during intubation and the more ergonomic handling of the laryngoscope. Before all experimental trials, each anesthetist performed a training session of 10 intubations per device in order to become familiar with the manikin and avoid any learning effect during the session. The task of each of them was effective intubated manikin simulating difficult airway, using the classic Macintosh blade laryngoscope (Trufatek, Israel), Intubrite (IntuBrite, UK), TrueView Evo2 (Trufatek, Israel) and the King Vision video laryngoscope (Ambu, Netherlands) (Photo 1).

Laryngoscopes are designed to be used by holding them in the left hand. The muscles involved into the laryngoscopy process are almost all the muscles of the left upper limb and left shoulder. We had to choose the mostly used muscles which create the highest workload for an operator. The direct laryngoscopy for endotracheal intubation requires elevating patients' structures of oral cavity and throat to create a direct line between an operator's eyes and a patient's entrance to larynx (Photo 2).

The idea of the classic laryngoscope operating is to hold still the laryngoscope in the palm, avoid any movements of wrist and create space in the mouth of the patient by elevating the whole forearm in such a way that the muscles mostly involved in this process are those a)

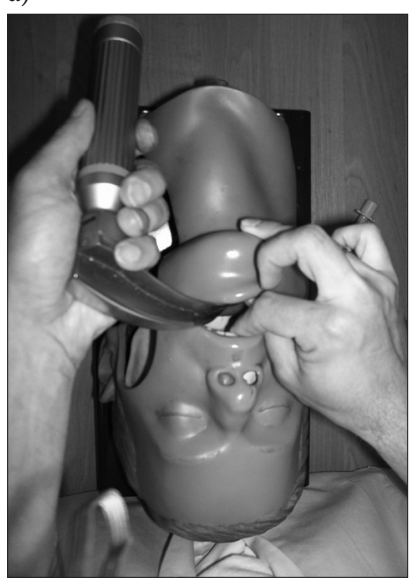

b)

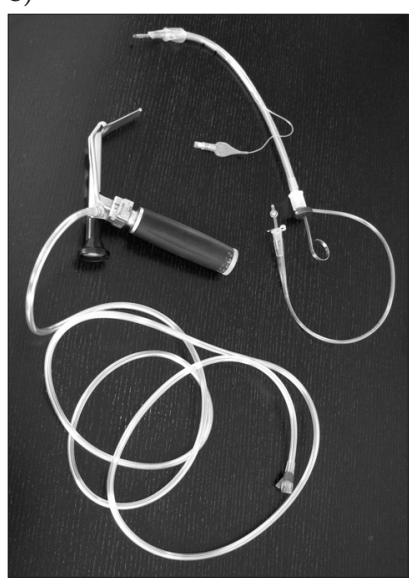

c)

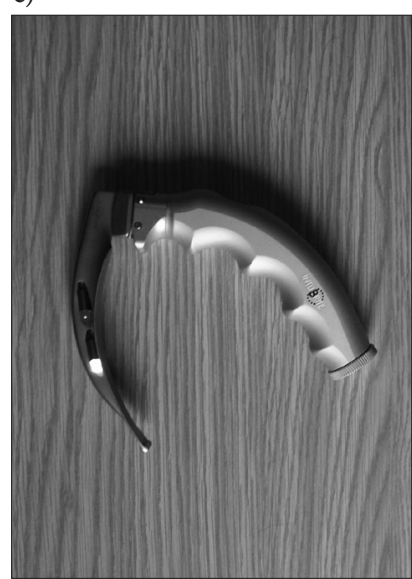

d)

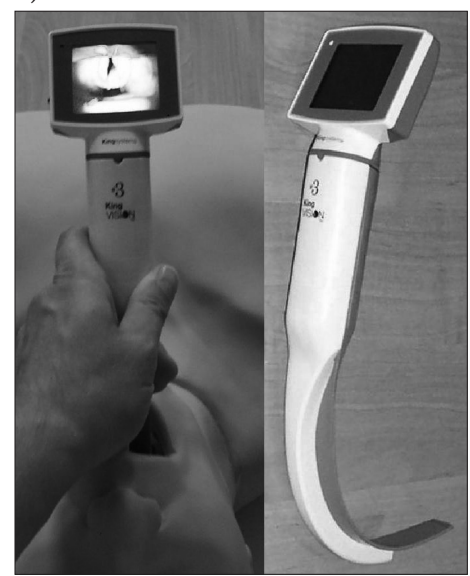

Photo 1. Studied devices: a) Macintosh blade standard laryngoscope (MCL), b) TruView 2 optical laryngoscope,

c) Intubrite laryngoscope, d) King Vision video laryngoscope

Fot. 1. Badane urządzenia: a) standardowy laryngoskop z łopatką Macintosha (Macintosh blade standard laryngoscope - MCL),

b) laryngoskop optyczny TruView Evo2, c) laryngoskop Intubrite, d) wideolaryngoskop King Vision 


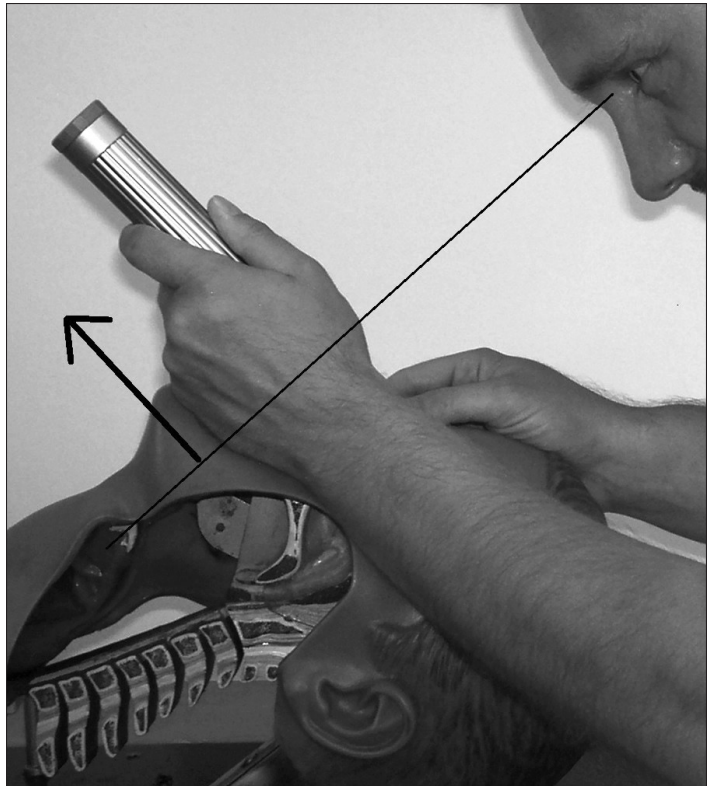

Left upper limb of intubation provider should be fixed in the wrist and movement of the limb should elevate mandible, to create space for direct visualisation of larynx, so there could be drawn a line between an operator's eyes and a patient's entrance to larynx. Line and arrow show the direction of elevation of mandible (applied force vector) and direction of direct observation of entrance to larynx / Lewa kończyna górna wykonującego intubację powinna być ustabilizowana w nadgarstku, a ruch kończyny powinien spowodować podniesienie żuchwy pacjenta w celu stworzenia miejsca na bezpośrednią obserwację wejścia do krtani, żeby możliwe było wykreślenie linii prostej między oczami intubującego a wejściem do krtani pacjenta. Linia i strzałka wyznaczają kierunek uniesienia laryngoskopu (wektor przykładanej siły) i kierunek bezpośredniej obserwacji wejścia do krtani.

Photo 2. Method of direct laryngoscopy method Fot. 2. Sposób wykonania laryngoskopii bezpośredniej

in the left arm and shoulder [2]. The studied muscles were: biceps brachii, triceps brachii and deltoideus in the left upper limb. Electrode placements followed the indications for the surface electromyography (sEMG) for the Non-Invasive Assessment of Muscles. To measure muscle activity, the MyoPlus 2 (Verity Medical, UK) with 2-channel sEMG test device was used (Photo 3). Muscle activity was evaluated by means of a computer program compatible with the MyoPlus 2 device.

For the purpose of the study, a commercial model of a head was used for intubation purposes - the Intubation Trainer (Laerdal, Norway). The head was positioned on a table in a sniffing position that was typical for intubation, however every participant could change the position if necessary. A silicone-lubricated $7.5 \mathrm{~mm}$ endotracheal tube reinforced with a malleable stylet was used for each intubation. The time of successful intubation was calculated as from the moment of grasping the device to the moment of confirming the tracheal tube positioning using a self-inflating bag. The participant's satisfaction with the studied devices was evaluated using the Visual

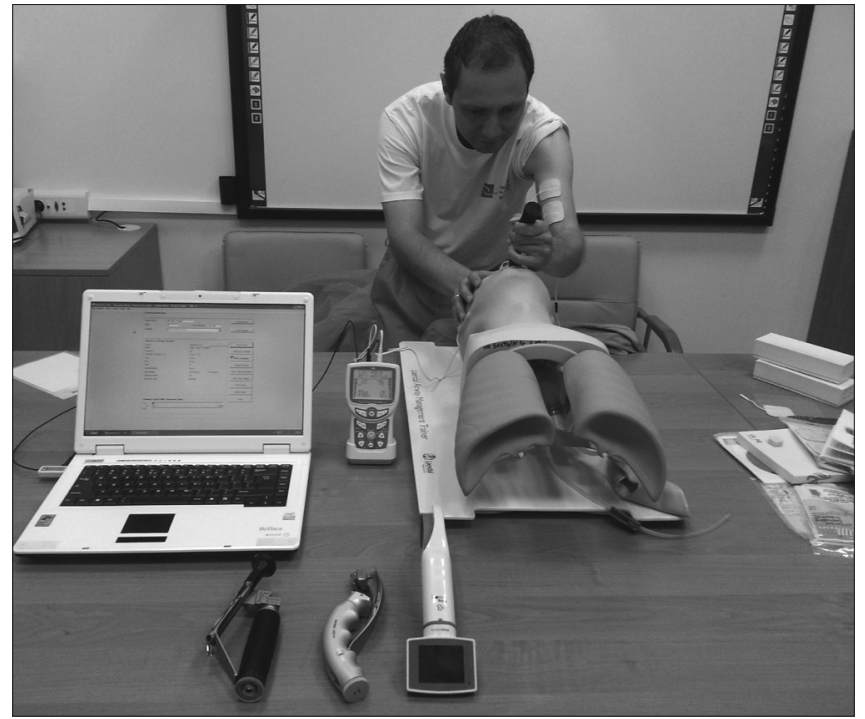

Photo 3. Experimental model - measurement of activity of muscles used during intubation efforts using computer program and MyoPlus 2 device

Fot. 3. Model badawczy - pomiar aktywności mięśni używanych $\mathrm{w}$ trakcie intubacji za pomocą oprogramowania komputerowego i aparatu MyoPlus 2

Analog Scale (0 - most difficult to use, 5 - most easy to operate). An operator's physical fatigue during intubation efforts was evaluated by means of the Borg's CR10 scale ( 0 - no fatigue, 10 - maximal efforts), modified by authors of this paper.

The resulting data was compiled and was analyzed statistically using the Microsoft Office Excell Package 2003 v11.5612.5606 (Microsoft, Warszawa, Poland). The $t$-test for pairs with variations was used. The sample size was not calculated because of a limited number of participants.

\section{RESULTS}

The example of muscle activity recording is presented in the Figure 1. The highest activity of all the studied muscles was observed for the Intubrite laryngoscope, followed by the one observed for the Mackintosh, TruView Evo2, and the lowest one - for the King Vision video laryngoscope, respectively:

- biceps brachii - $60.8 \mu \mathrm{V}$ (standard deviation $(\mathrm{SD})=33.7)$ vs. $52 \mu \mathrm{V}(\mathrm{SD}=28.7)$ vs. $49.7 \mu \mathrm{V}$ $(\mathrm{SD}=25.3)$ and $21.6 \mu \mathrm{V}(\mathrm{SD}=14.6)$,

triceps brachii $-18.9 \mu \mathrm{V}(\mathrm{SD}=7.6)$ vs. $17.9 \mu \mathrm{V}$ $(\mathrm{SD}=7.6)$ vs. $13.7 \mu \mathrm{V}(\mathrm{SD}=6)$ and $8.1 \mu \mathrm{V}(\mathrm{SD}=6.4)$, deltoideus - 38.1 $\mu \mathrm{V}(\mathrm{SD}=22.8)$ vs. $36.1 \mu \mathrm{V}$ $(\mathrm{SD}=20.6)$ vs. $29.4 \mu \mathrm{V}(\mathrm{SD}=14.2)$ and $13.1 \mu \mathrm{V}$ $(\mathrm{SD}=7.4)$, 


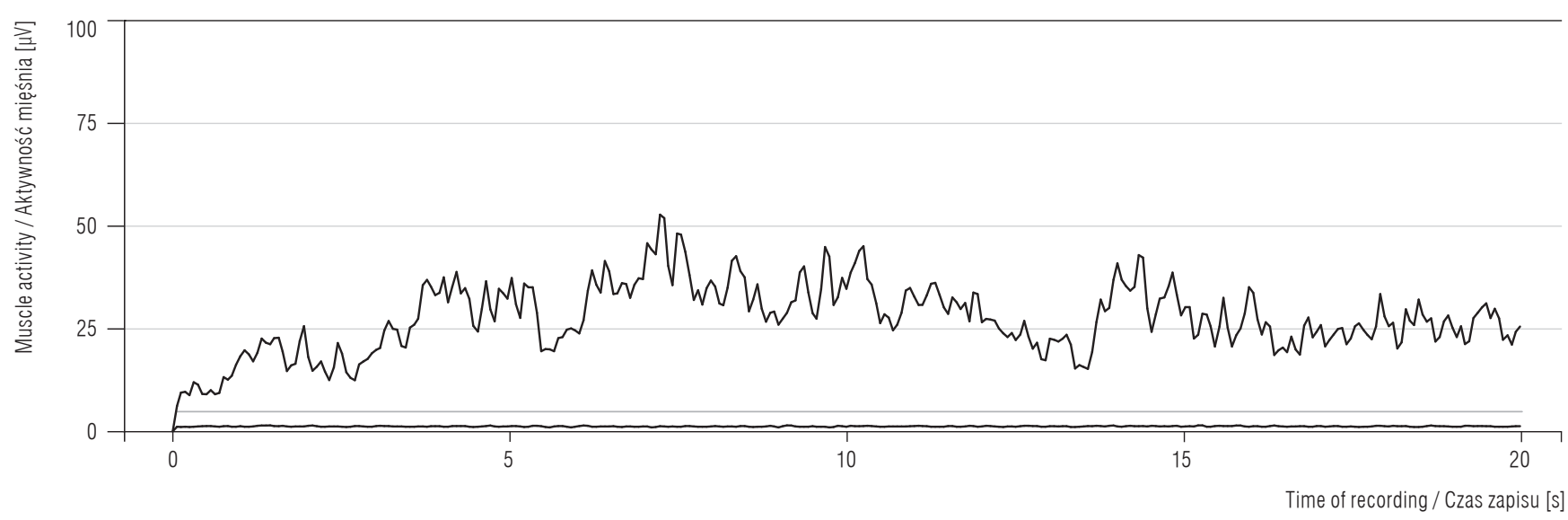

Fig. 1. Example of recording muscle activity during intubation efforts using MyoPlus 2 device

Ryc. 1. Przykładowy zapis aktywności mięśni za pomocą urządzenia MyoPlus $2 \mathrm{w}$ trakcie prób intubacji

The significant statistical difference was observed for the King Vision and the rest of the laryngoscopes in the case of 3 evaluated muscles (Table 1), and between the TruView
Evo2 and the Intubrite laryngoscopes regarding the function of triceps brachii. Results of muscle activity measurements are presented in the Figure 2 and the Table 1.

Table 1. Muscle activity in subjects performing laryngoscopy using evaluated laryngoscopes

Tabela 1. Aktywność mięśni u osób wykonujących intubację z użyciem badanych laryngoskopów

\begin{tabular}{|c|c|c|c|c|c|}
\hline \multirow{2}{*}{$\begin{array}{l}\text { Mięsień } \\
\text { Muscle }\end{array}$} & $\begin{array}{c}\text { Muscle activity } \\
\text { Aktywność mięśnia } \\
(\mathrm{N}=13)\end{array}$ & \multicolumn{4}{|c|}{$\mathrm{p}$} \\
\hline & $\begin{array}{l}\min .-\max \\
\text { min.-maks. }\end{array}$ & M & Intubrite & TruView & King Vision \\
\hline \multicolumn{6}{|l|}{ Triceps brachii } \\
\hline MCL & $6.2-31.6$ & 17.89 & 0.3577 & 0.0690 & 0.0008 \\
\hline Intubrite & $7.8-30.8$ & 18.99 & - & 0.0327 & 0.0003 \\
\hline TruView Evo2 & $4.8-24.8$ & 13.76 & - & - & 0.0149 \\
\hline King Vision & $2.5-28.2$ & 8.10 & - & - & - \\
\hline \multicolumn{6}{|l|}{ Deltoideus } \\
\hline MCL & $12.5-81.9$ & 36.12 & 0.4107 & 0.1737 & 0.0009 \\
\hline Intubrite & $14.5-85.0$ & 38.07 & - & 0.1307 & 0.0011 \\
\hline TruView Evo2 & $8.3-54.8$ & 29.45 & - & - & 0.0009 \\
\hline King Vision & $3.0-27.7$ & 13.13 & - & - & - \\
\hline \multicolumn{6}{|l|}{ Biceps brachii } \\
\hline MCL & $15.5-104.0$ & 52.04 & 0.2403 & 0.4146 & 0.0016 \\
\hline Intubrite & $18.4-118.0$ & 60.85 & - & 0.1761 & 0.0007 \\
\hline TruView Evo2 & $14.2-90.9$ & 49.72 & - & - & 0.0013 \\
\hline King Vision & $6.1-61.2$ & 21.65 & - & - & - \\
\hline
\end{tabular}

Full names of laryngoscopes as at Photo 1 / Pełne nazwy laryngoskopów jak na fotografii 1.

$\mathrm{N}$ - number of respondents / liczba badanych, min. - minimal value / wartość minimalna, max / maks. - maximal value / wartość maksymalna, M - mean / średnia. 
a)

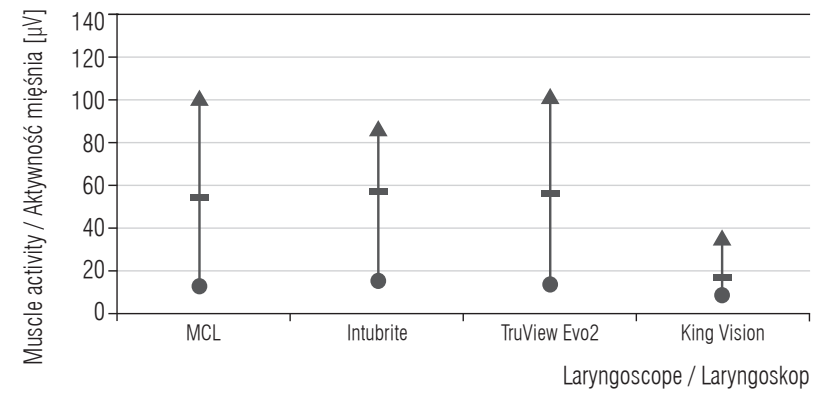

b)

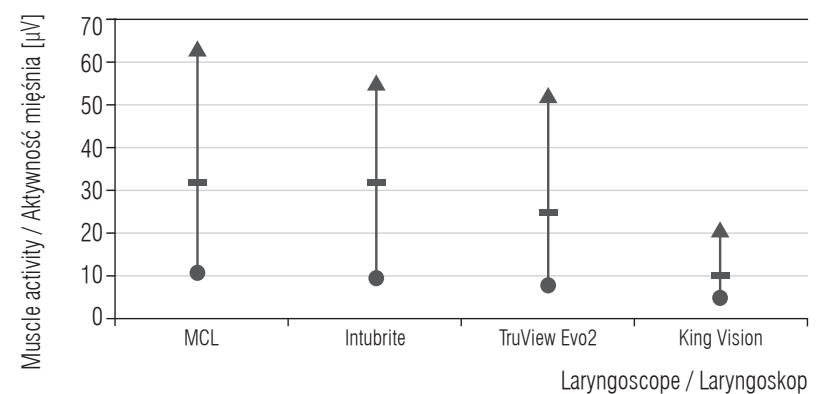

c)

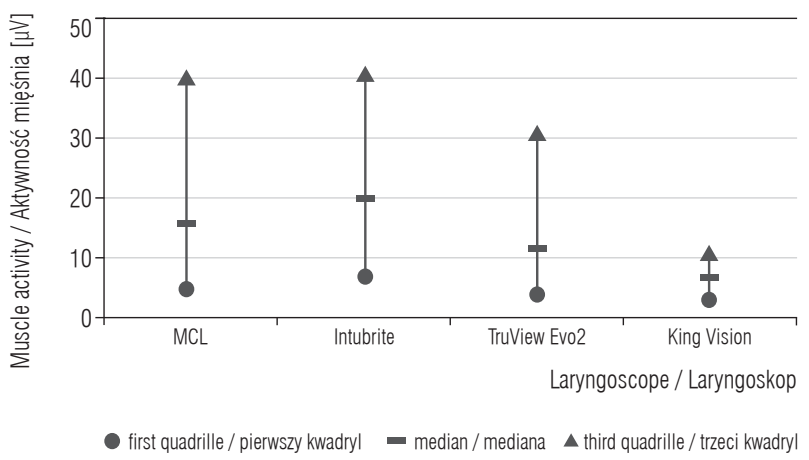

Full names of laryngoscopes as at Photo 1 / Pełne nazwy laryngoskopów jak na fotografii 1 .

Fig. 2. Muscle activity of intubation providers: a) biceps brachii, b) deltoideus, c) triceps brachii Ryc. 2. Aktywność mięśni u wykonujących intubację:

a) dwugłowego ramienia, b) naramiennego, c) trójgłowego ramienia
Results of time of intubation calculations are presented in the Table 2 . The shortest time of intubation was achieved using the Intubrite laryngoscope, a similar result was achieved using the standard Macintosh blade laryngoscope and the King Vision video laryngoscope, and the longest time - using the TruView Evo2, and the significant statistical difference was observed when comparing the TruView Evo2 with all other laryngoscopes (Table 2).

The highest satisfaction was noted for the King Vision video laryngoscope, and a similar result was reported for the standard Macintosh blade laryngoscope and the Intubrite laryngoscope $(\mathrm{p}>0.05)$, and the lowest satisfaction - for the TruView Evo2 ( $p<0.05$ comparing to King Vision). The Intubrite was the most demanding in terms of the physical workload in the opinion of participants', and the least demanding was the King Vision video laryngoscope. Results are presented in the Table 3 and 4.

\section{DISCUSSION}

The ergonomics of laryngoscopy and tracheal intubation, which involve the physical interaction between the operator and the working environment (equipment) and the underlying psychological and cognitive elements responsible for such an interaction, constitute the subject matter of the research at issue. Intubation is biomechanically defined as a complex multi-joint procedure that activates the operator's upper limb muscles during a short period of time [1]. The energy developed by muscles is transmitted to the patient's airway through the laryngoscope in the form of horizontal and perpendicular forces to expose the glottis.

Table 2. Time of successful intubation of manikin using studied laryngoscopes

Tabela 2. Czas potrzebny do prawidłowego zaintubowania manekina z użyciem badanych laryngoskopów

\begin{tabular}{|c|c|c|c|c|c|}
\hline \multirow[t]{2}{*}{$\begin{array}{l}\text { Laryngoscope } \\
\text { Laryngoskop }\end{array}$} & \multicolumn{2}{|c|}{$\begin{array}{l}\text { Time of intubation } \\
\text { Czas intubacji } \\
(\mathrm{N}=13) \\
{[\mathrm{s}]}\end{array}$} & \multicolumn{3}{|c|}{$\mathrm{p}$} \\
\hline & $\begin{array}{l}\min .-\max \\
\text { min.-maks. }\end{array}$ & $\mathrm{M} \pm \mathrm{SD}$ & Intubrite & TruView Evo2 & King Vision \\
\hline MCL & $3.00-22.00$ & $8.25 \pm 4.08$ & 0.3722 & $<0.001$ & 0.3035 \\
\hline TruView Evo2 & $5.00-40.00$ & $16.00 \pm 8.85$ & - & - & $<0.001$ \\
\hline King Vision & $3.00-24.00$ & $8.82 \pm 5.45$ & - & - & - \\
\hline
\end{tabular}

Full names of laryngoscopes as at Photo 1 / Pełne nazwy laryngoskopów jak na fotografii 1.

SD - standard deviation / odchylenie standardowe. Other abbreviations as in Table 1 / Inne skróty jak w tabeli 1. 
Table 3. Evaluation of intubation providers' satisfaction with the use of studied devices

Tabela 3. Ocena satysfakcji osób przeprowadzających intubację z użyciem badanych laryngoskopów

\begin{tabular}{|c|c|c|}
\hline \multirow{2}{*}{$\begin{array}{l}\text { Laryngoscope } \\
\text { Laryngoskop }\end{array}$} & \multicolumn{2}{|c|}{$\begin{array}{l}\text { Satisfaction } \\
\text { Satysfakcja* } \\
\quad(N=13)\end{array}$} \\
\hline & $\begin{array}{l}\min .-\max \\
\text { min.-maks. }\end{array}$ & $\mathrm{M} \pm \mathrm{SD}$ \\
\hline MCL & $1.00-5.00$ & $3.66 \pm 1.02$ \\
\hline Intubrite & $1.00-5.00$ & $3.60 \pm 0.92$ \\
\hline TruView Evo2 & $1.00-5.00$ & $3.52 \pm 0.90$ \\
\hline King Vision & $2.00-5.00$ & $3.78 \pm 0.91$ \\
\hline
\end{tabular}

Full names of laryngoscopes as at Photo 1 / Pełne nazwy laryngoskopów jak na fotografii 1 .

* Visual Analog Scale (VAS) / wizualna skala analogowa VAS: 0 - most difficult to use / najtrudniejsze w użyciu, 5 - most easy to use / najłatwiejsze w użyciu. Abbreviations as in Table 1 and 2 / Skróty jak w tabeli 1 i 2.

Table 4. Evaluation of intubation providers' fatigue when using studied devices

Tabela 4. Ocena zmęczenia osób przeprowadzających intubację w trakcie użycia badanych urządzeń

\begin{tabular}{|c|c|c|}
\hline \multirow{2}{*}{$\begin{array}{l}\text { Laryngoscope } \\
\text { Laryngoskop }\end{array}$} & \multicolumn{2}{|c|}{$\begin{array}{c}\text { Fatigue }^{*} \\
\text { Zmęczenie }^{*} \\
(\mathrm{~N}=13)\end{array}$} \\
\hline & $\begin{array}{l}\min .-\max \\
\min .- \text { maks. }\end{array}$ & $\mathrm{M} \pm \mathrm{SD}$ \\
\hline MCL & $0.00-7.00$ & $2.58 \pm 1.69$ \\
\hline Intubrite & $0.00-7.00$ & $3.02 \pm 1.58$ \\
\hline TruView Evo2 & $0.00-6.00$ & $2.94 \pm 1.37$ \\
\hline King Vision & $0.00-7.00$ & $2.42 \pm 1.67$ \\
\hline
\end{tabular}

Full names of laryngoscopes as at Photo 1 / Pełne nazwy laryngoskopów jak na fotografii 1.

* Modified Borg's scale / Zmodyfikowana skala Borga: 0 - no fatigue / brak zmęczenia, 10 - maximal efforts / maksymalny wysiłek.

Abbreviations as in Table 1 and 2 / Skróty jak w tabeli 1 i 2.

The traditional direct laryngoscopy using the Macintosh laryngoscope blade requires the line-of-sight alignment of the patient's mouth, pharynx, and larynx and adjustment of body posture to gain binocular vision and produce optimal lifting and pushing [2].

The laryngoscope Intubrite is advertised by the manufacturer as a new, ergonomic shape handle. In our study it has been found to be the most demanding in terms of muscle work. The TruView Evo2 laryngoscope is designed for difficult intubation and should allow to use less strength to intubate as compared to the Macintosh laryngoscope. This was observed in our study. Video laryngoscopes constitute a group of airway de- vices which allow to intubate with the smallest use of force, mitigating the risk of airway injuries. The idea of using video laryngoscopes instead of a classic direct laryngoscopy device which is the Macintosh blade laryngoscope is to project laryngeal view to monitor that and allow to separate operation area - oral cavity and pharynx from visualization area. The video laryngoscopes allow to visualize entrance to larynx using less maneuvers and potentially less force. All these factors contribute to reduction of the task workload that is defined as the cost incurred by the operator to achieve a particular level of task [3]. We observed this also in our study, as the video laryngoscope King Vision required the smallest muscle activity during intubation efforts. That suggests that if it is used for prolonged intubation efforts or multiple intubation attempts, it will cause the smallest physical fatigue of a provider.

The induction phase (including intubation) is a period of high workload in anesthesia clinical practice. The interaction between operators and their working environment during laryngoscopy is poorly understood. Numerous studies have focused on the forces applied to the patient's airway during laryngoscopy, but only few authors have addressed an operator's muscle activity and workload. There is a very small number of works evaluating muscle activity or work force of a provider during intubation procedure [1]. Those available ones rather concentrate on an intubator's posture or movement than on work load of this procedure [4].

The anesthetists report a perception of less fatigue and better ease of use in the case of the video laryngoscopes but the components of perceived workload during laryngoscopy have not been clarified $[5,6]$.

During the last 30 years, numerous investigators have studied the forces applied to manikins or the patient's airway during laryngoscopy [7-13], but only few researchers have focused on the operator's muscular activity and effort during the direct and indirect laryngoscopy [5,14].

Since generating the appropriate force constitutes a possible limiting factor, video laryngoscopes could be useful to avoid errors due to the difficulty of laryngoscopy and differences in physical strength typically identified in novice females [15]. Nevertheless, the relationship between force and error during laryngoscopy has not been demonstrated and further studies are needed.

The muscular fatigue is a significant problem during the direct laryngoscopy and the introduction of more ergonomically efficient devices would decrease taskrelated workload. 
The muscle fatigue may be a significant problem during intubation efforts especially in the case of difficult intubation or/and difficult conditions for an operator, therefore introduction of more ergonomically efficient devices would decrease task-related workload.

Byrne and colleagues [16] validated a novel quantitative method to assess an anesthetist workload and emphasized that reducing workload in anesthesia is a prominent issue for a safe clinical practice. As a confirmation, $64 \%$ of anesthetists ascribe performance errors to excessive workload [17].

In anesthesia practice, Weinger considers that the potential clinical benefits arising from the use of airway management strategies may be partially offset by increased workload or a reduced ability to attend to unanticipated problems or new task demands [18]. In modern anesthesiology, the main cause of serious complications, including hypoxic brain injury is connected to difficulties with airway management and oxygenation [19]. Especially in selected groups of patients like morbidly obese, because of body composition and airway anatomy, forces necessary to visualize entrance to larynx using standard laryngoscopes are significantly higher, thus the workload during intubation attempts is increased [20]. New ergonomic devices for airway management may improve situation.

In our work the shortest time of intubation was achieved with the Intubrite laryngoscope, although it required the highest workload. This suggests that the Intubrite laryngoscope, which is advertised as an ergonomic device, is the most demanding device, however it may be useful because it assures the best time of successful intubation.

Based on our results and the literature, a more ergonomic instrument, such as video laryngoscopes, will reduce physical workload and potentially enhance clinical safety.

\section{Study limitations}

A major limitation of the study was the use of the manikin, although it was intended to avoid inter-patient variability because it limits the generalizability of the results to clinical practice. Given the small sample size and the use of a manikin study model, the conceptual framework of this study is that of a pilot study with very limited generalizability, and therefore it rather constitutes a proof of concept. The validity and accuracy of non-invasive muscle activity testing is lower as compared to invasive methods but in this case invasive monitoring would not be recommended because of safety and ethics issue.

\section{CONCLUSIONS}

Muscle activity, namely the force used for intubation, is the smallest when the King Vision video laryngoscope is used with the highest satisfaction and lowest workload, and the highest muscle activity was for the Intubrite laryngoscope with the highest workload.

\section{REFERENCES}

1. Caldiroli D, Molteni F, Sommariva A, Frittoli S, Guanziroli E, Cortellazzi P, et al. Upper limb muscular activity and perceived workload during laryngoscopy: Comparison of Glidescope ${ }^{\oplus}$ and Macintosh laryngoscopy in manikin: An observational study. Br J Anaesth. 2014;112(3): 563-9, http://dx.doi.org/10.1093/bja/aet347.

2. Carlson JN, Das S, Spring S, Frisch A, de la Torre F, Hodgins J. Assessment of movement patterns during intubation between novice and experienced providers using mobile sensors: A preliminary, proof of concept study. BioMed Res Int. 2015;2015, http://dx.doi.org/10.1155/2015/843078.

3. Grundgeiger T, Happel O, Grundgeiger J, Roewer N. Body posture during simulated tracheal intubation: Comparison of the effects of video laryngoscopy and direct laryngoscopy. Proc Hum Factors Ergon Soc Annu Meet. 2014;58(1):768-72, http://dx.doi.org/10.1177/ 1541931214581140

4. Walker DJ. Posture used by anaesthetist during laryngoscopy. Br J Anaesth. 2002;89(5):772-4, http://dx.doi. org/10.1093/bja/89.5.772.

5. Latif RK, Akca O. Simulation based training of airway management with Macintosh blade and Glidescope video laryngoscope. Minerva Anestesiol. 2011;77:1-3.

6. Kahn S, Cooper RM. Superior glottic views with Glidescope and Airtraq laryngoscopes compared with an anterior commissure laryngoscope. Can J Anaesth. 2011; 58:224-5, http://dx.doi.org/10.1007/s12630-010-9413-2.

7. Savoldelli GL, Schiffer E, Abegg C, Baeriswyl V, Clerque F, Waeber JL. Comparison of the Glidescope, the McGrath, the Airtraq and the Macintosh laryngoscopes in simulated difficult airways. Anaesthesia. 2008;63:1358 64, http://dx.doi.org/10.1111/j.1365-2044.2008.05653.x.

8. Carassiti M, Biselli V, Cecchini S, Zanzonico R, Schena E, Silvestri S, et al. Force and pressure distribution using Macintosh and Glidescope laryngoscopes in normal airway: An in vivo study. Minerva Anestesiol. 2013;79:515-24.

9. Nastasia I, Lortie M, Delisle A, Gagnon M. Perception and biomechanics data in a manual handling task: A comparative study. Ergonomics. 2007;50:2059-81, http://dx.doi.org/10.1080/00140130701369387. 
10. Russell T, Kahn S, Elman J, Katznelson R, Cooper RM. Measurement of forces applied during Macintosh direct laryngoscopy compared with GlideScope videolaryngoscopy. Anaesthesia. 2012;67:626-31, http://dx.doi. org/10.1111/j.1365-2044.2012.07087.x.

11. Carassiti M, Zanzonico R, Cecchini S, Silvestri S, Cataldo R, Agrò FE. Force and pressure distribution using Macintosh and Glidescope laryngoscopes in normal and difficult airway: A manikin study. Br J Anaesth. 2012;108: 147-51, http://dx.doi.org/10.1093/bja/aer304.

12. Lee RA, van Zundert AAJ, Maassen RLJ, Wieringa PA. Forces applied to the maxillary incisors by video laryngoscopes and the Macintosh laryngoscope. Acta Anaesthesiol Scand. 2012;56:224-9, http://dx.doi.org/10.1111/ j.1399-6576.2011.02541.x.

13. Russell T, Lee C, Firat M, Cooper RM. A comparison of the forces applied to a manikin during laryngoscopy with Glidescope and Macintosh laryngoscopes. Anaesth Intensive Care. 2011;39:1098-102.

14. Pandian A, Raval M, Bailey CR. A non-airway management use of the video laryngoscope (GlideScope ${ }^{\circ}$ ). Eur J Anaesthesiol. 2008;25:511, http://dx.doi.org/10. $1017 /$ S0265021507002906.
15. Waddington MS, Paech MJ, Kurowski HS, Reed CJ, Nicholls GJ, Guy DT, et al. The influence of gender and experience on intubation ability and technique: A manikin study. Anaesth Intensive Care. 2009;37:791-801.

16. Byrne AJ, Oliver M, Bodger O, Barnett WA, Williams D, Jones $\mathrm{H}$, et al. Novel method of measuring the mental workload of anaesthetists during clinical practice. Br J Anaesth. 2010;105:767-71, http://dx.doi.org/10.1093/bja/aeq240.

17. Gaba DM, Lee T. Measuring the workload of the anesthesiologist. Anesth Analg. 1990;71:354-61, http:// dx.doi.org/10.1213/00000539-199010000-00006.

18. Weinger MB. Quantitative description of the workload associated with airway management procedures. J Clin Anesth. 2000;12(4):273-82, http://dx.doi.org/10.1016/ S0952-8180(00)00152-5.

19. Woloszczuk-Gebicka B, Zawadzka-Glos L, Lenarczyk J, Sitkowska BD, Rzewicka I. [Two cases of "cannot ventilate, cannot intubate" scenario in children in the view of recent recommendations]. Anaesthesiol Intensive Ther. 2014;46: 88-91, http://dx.doi.org/10.5603/AIT.2014.0017. Polish.

20. Gaszynski T. Clinical experience with the C-Mac videolaryngoscope in morbidly obese patients. Anaesthesiol Intensive Ther. 2014;46:14-6, http://dx.doi.org/10.5603/ AIT.2014.0003.

This work is available in Open Access model and licensed under a Creative Commons Attribution-NonCommercial 3.0 Poland License / Ten utwór jest dostępny w modelu open access na licencji Creative Commons Uznanie autorstwa - Użycie niekomercyjne 3.0 Polska - http://creativecommons.org/ licenses/by-nc/3.0/pl/deed.en. 